DOI: $10.21554 /$ hrr.092004

\title{
BOSNIAN LANGUAGE AND BOSNIAKS
}

\section{Professional paper}

\author{
Ahmet Kasumović ${ }^{1}$ \\ Institute for Human Rehabilitation, Tuzla, Bosnia and Herzegovina
}

Received: 5/14/2020

Accepted: 8/30/2020

\begin{abstract}
Bosnian language is a very important factor of Bosniak identity. It owns active and passive vocabulary. Bosniak identity is confirmed by the Bosnian language. Identity and language are causally linked.
\end{abstract}

Key words: language, identity, bilingualism, folklore, global interests

BOSNIAN LANGUAGE AND BOSNIAKS

Language is man's greatest freedom (Anić, 1998) and no one has the right to judge a man by the language he speaks. The voice of mother tongue is adopted already in bladder and it cannot be deleted by anything. One is totally free in choice of words, in building words in syntagmatic and sentence constructions, and within context of the language structure (grammar) which he considers his or her own internal (own, national, ancient...) language. Through its language, one preserves its identity, for language reliably stores tradition, custom, folklore, work and everything else through which individual and collective are expressed. That means that, by language, as very important creator and preserver of identity, history is also preserved, and religion, and art, geography, anthropological values and many other values of individual, nation, state, society etc.

However, new technologies, modern flows of humanity development, new profiles of state, society, religion, nation and everyday needs for numerous and very far communication and understanding, before many linguists, but also before every man, have created a significant problem: global language - local language (unification, assimilation, dying or parallel survival, bilingualism, common language, understanding and local language of national folklore). Since, in both variances, it more or less represents the question of identity, it is a fact that with slight deviation, an equality sign can be put between national language and identity.

\footnotetext{
${ }^{1}$ Correspondence to:

Ahmet Kasumović, PhD, Institute for Human Rehabilitation, Tuzla, Bosnia and Herzegovina

Mosnik 29, 75000 Tuzla, Bosnia and Herzegovina

Phone:+387 61101230

E-mail: ahmetkasumovic@gmail.com
} 
With the fact that English language is more and more a global language, for Bosnian language, it can be said that it is, besides other things, a factor of Bosniak identity, but also of all others who inside or outside of Bosnia and Herzegovina feel Bosnian language as inextricable part of their own colloquial feeling.

David Crystal (2009), the author who wrote about English language for Cambridge University Press, considers that language has global status in moment when it gets special role recognized in every country. That role is evident in countries where people speak that language as their mother tongue. When it comes to English language, those countries are: United States of America, Great Britain, Canada, Ireland, Australia, New Zealand, South Africa and the Caribbean. But only the usage of mother tongue does not give a global status to that language, because language must be accepted in other countries around the world, meaning also in countries where there are no native speakers of that language. That status can be achieved through marking some language as official, i.e. that language is used as means of communication in government, judiciary, media and educational system. The best example of official language today is English language which today has (global) special status in more than 70 countries. This position is more than any other language has ever achieved, although French, German, Spanish, Russian and Arabic languages also have significant official use.

Other way of gaining special status is giving priority in teaching certain language, even when that language does not have official status. English language is thought as a foreign language in more than 100 countries around the world, and from 1996 English has replaced French and is thought again as foreign language in schools of Algeria (ex French colony).

When it comes to identity, it is interesting why one language becomes global language regardless of number of speakers? Crystal states that this is the matter of who speaks that language. Latin has become an international language in Roman Empire, not because the Romans were most numerous, but because they were most powerful. Analogue to that, without strong political, military or economic power, no language can prosper as international mean of communication. Crystal (2002:7-8) concludes that language becomes international due to political, military and economic power of certain nation. English language is no exception. British political imperialism has spread English language all over the world in $19^{\text {th }}$ century. During the $20^{\text {th }}$ century, the presence of English language has kept and continued through economic predominance of the new American force. And the language that stands in front of, besides and behind American dollar is English.

How many languages in the world today has such kind of support and where within those frames is Bosnian language as factor of Bosniak identity?

Significant usages thrive from the existence of global language, but there is also certain risk i.e. possible consequences. Maybe the existence of global language will accelerate the disappearance of minority languages or maybe the final threat will come true that all other languages will become unnecessary. To some, that idea is partly materialized, which is confirmed through existence of artificial universal language of Esperanto. Vice-president of Esperanto society dr. Lee Chong-Yeaong stresses that the problem of language in UN system is hegemonic status given to English language, which will result in language hegemony. Crystal also considers possible consequences which occur with global status of some language, in this case English language. Before all, Crystal speaks of linguistic advantage. Real risk is that people, to whom a global language is mother tongue, will be in advantage in relation to those who must learn it as foreign or official language. That means that scientists, to whom English language is not mother tongue, will have difficulties in realization of creative work, or that their works will, if they are written in mother tongue, be ignored in international community. As solution for this problem, Crystal proposes that global language should be introduced into educational system as soon as possible, so that language capacity could be achieved in time. Second consequence of which he speaks is linguistic complacency. 
People, to whom global language is mother tongue, lose motivation for learning other foreign languages. Sometimes the reason is of financial nature, but mostly it is a lack of interest, because whether they visit other countries as tourists or that they are simply using internet, native speakers of English language encounter it everywhere.

Such fate is awaited by the Bosnian language too. However, even if it does go to folklore, does that mean that cohesive power of Bosniak (and other) identity ceases to exist in Bosnia and Herzegovina. Bosnian language is not global, but it is global in colloquial sense of the people, the country, administration, even for centuries, so in that way, it became a national treasure chest and state treasury and historic linguistic archive. Another consequence of existence of global language is so called linguistic death. However, through history, it is shown that domination and disappearance of some languages have developed independently of the existence of global language. Some languages ceased to exist because the nations who spoke them were assimilated into dominant society and have accepted its language. Once language disappears, a lot is lost for good, especially if language was never written down. Identity of people is lost. Scientists who have gathered at a meeting of AAAS (American Association for Advancement of Science) in Seattle, Washington, warned that half of the languages which are spoken today will disappear by the end of this century.

Through disappearance of some language, a national and cultural identity of certain nation is at question. Crystal proposes solution for this problem - bilingualism, whereby people would speak global language as mean of access to world community and the language of the region in which they live due to communication in that region. The functions of these two languages would be complementary and would meet different needs. We can assume that many have the same opinion for two reasons: preserve the local language and preserve national/state and/or other identity. It would be solution for Bosnia and Herzegovina too, and for Bosnian language.
When we consider minority languages and the possibility of their disappearance, there are also other reasons which question that disappearance. If we take for example Bosnian language, we can see that, especially in after war situation in Bosnia and Herzegovina, there are many reasons which support further existence of Bosnian as life language, than reasons which would make us think that, within appropriate time, Bosnian language could only be preserved in written or electronic form. Before all, because of warfare which recently ended in Bosnia and Herzegovina, the conscience of people on the importance of language as national identity has increased. However, people have also seen a great need for usage of global i.e. English language in modern and developed society. Although English language is imposed on cultural field and is present in daily life of Bosnians and Herzegovinians (television, music, internet, press and similar), still, on the other hand, the presence of Bosnian language in those and other fields is greater. The fact that mother tongue is adopted without any effort in early childhood, and the fact that a tremendous effort must be put into learning foreign language, speaks to the favour of further survival and wide usage of Bosnian language. When we consider the number of speakers of this language, without taking into consideration the existence of wide diasporas which already partly ceases to use Bosnian language and overtakes the language of the country where they are currently situated, still, in Bosnia and Herzegovina itself, there is a large number of people who use Bosnian language in daily use. Entrance into the European Union requires retention of own identity in national languages as characteristic of certain nation and for communication in certain region, but also the introduction of global language as mean of understanding within the Union. Stated reasons assume survival of Bosnian language as minority language. Important contribution to that is the fact that, through language, identity forms itself for years and centuries, so the assumption of disappearance of language is conditioned by disappearance of identity. 
Since the changes of social awareness happen very slowly (as per some, in seventy years), centuries are needed for change of identity. It is even questionable whether it can happen until the end, for language, most often, permanently remains in onomastics (less in anthroponomastics and much more in toponomastics). All current hydronims are older than toponyms, many toponyms, hydronims, oronyms etc. by arrival of a new nation and language have kept their original name, or they have formed it as calque. Even today that is the case with Bosnia and Herzegovina, Bosniaks, Bosnian language (even in anthroponomastics: ĐulaRuža, Nura-Svjetlana, Demir-Gvozden, MelakaAnđela...). Language remains in work, customs, culinary, social forms of living, etc. Still, one should not doubt that language can roughly administratively be exterminate, through pseudostandardization, denationalization in all ways and daily assimilation, elimination, pseudoarchaisation, as well as in other ways. Language is best preserved by those who speak it and who feel it as important factor of their own, family, national, state-building identity.

For English language, the way in which cultural heritage of colonial era and technological revolution are present on international scene is very important. English language occurred as means of communication in development countries which gradually shaped the character of daily and professional life of $20^{\text {th }}$ century.

Global presence of English language gives it the possibility and strength of cultural imperialism. English is official language of many international political gatherings, institutions and organizations such as: United Nations, South African Nation Society, Commonwealth, Council of Europe and the European Union. Today, any kind of consideration of politics leads to the role of media. Newspapers such as: The New York Times, The Washington Post, The Wall Street Journal, The Times and The Sunday Times are the leading in the world, and are published in English language. Newspapers of great importance International Herald-Tribune, US Weekly and International Guardian intended for world readers, are also printed in English. Massive production has increased the flow of goods and imposed competition among producers. Posters, billboards, illuminated advertising are part of daily life, and with expansion of world market they are more and more manifestations of English language. When it comes to broadcasting of the Voice of America, service for broadcasting outside of the country, broadcast program from the United States in English and 45 other languages across the world, together with Freedom Radio and Free Europe Radio. Development of technology has significantly changed the nature of home and public amusement, and by that also broke a path for development and expansion of English language. In mid nineties of past century, the United States have controlled 85 percent of world movie market of Hollywood movies which dominated in cinemas across the world. So, large number of movies which are shown in cinemas and on television are in English language (usually with sub-titles). Crystal states one more type of amusement which new technology has improved, and which arose at the end of $19^{\text {th }}$ century - music industry. Today, radio all over the world witnesses domination of English language in popular music. In past century 70-ies, world fame was achieved by Swedish pop group ABBA singing in English language. Crystal states data from encyclopedia The Penguin Encyclopedia of Popular Music that in 1990 out of 557 pop groups, 549 of them (99 percent) sung exclusively or mostly in English language. On basis of above stated, it can be concluded that domination of one language on cultural, political and economic level actually represents sort of imperialism and attempt of expansion of influence of certain countries on wide territories through language. Bosnia and Herzegovina and Bosnian language are exposed to such influences. For now, there are no more reliable shapes of resistance than its Bosnian lingual feeling as a strong factor of individual and collective identity.

Another exceptionally important segment of global society is under domination of English language today, an international media, because of which we often hear phrase "global village", and that is internet. 
Through internet, not only that people all over the world who have access to computer are connected with each other, but also it has a large number of information for all users. Crystal mentions the fact that around 80 percent of electronically saved information in the world is in English language. It is also important to mention that all systems for data transfer through network are made for English alphabet, which significantly aggravates the existence of multi-language systems for data transfer having in mind that Arabic, Chinese or other alphabets have special symbols. It is not only a matter of textual content, but also of the money, measuring systems, dates and other specific conventions.

Designing of such systems which in future will give bilingual data presentation represents a long-term goal, but until then, lingua internet will obviously be English. So, internet users, besides knowledge of computers, also need to have English language knowledge if they want to use the advantages that internet offers, by which English becomes the largest and most effective American "product" for export. Citizens of Bosnia and Herzegovina are exposed to such influences, but they need not be assimilatory, but on the contrary they can help in motivation to preserve own language and identity.

English language domination is evident in modern society, but the opinions of whether that will be the case in the future are divided. Crystal considers that the position of English language as global language is secured, but one must be careful with predictions when it comes to language. He bases his opinion on the fact that no language has ever been so widespread nor used as English. Relation between the need for mutual understanding and identity is sensitive, and can easily be disrupted by social changes such as new political alliances and changes in status and politics of certain country.

However, there is no doubt that those nations and those countries which culturally close themselves are losing for sure. Each sealing, even linguistic, means impoverishment, isolation. Meeting the other and accepting something that is a need and necessity in own development, does not mean losing own identity. In language that is specially seen (Kordić, 2010) because even when some foreign words are accepted, they most often remain as lexical choice between the two or more words, they ease linguistic marking, weaken or strengthen expression, etc. That however does not mean that one must advertise the usage of foreign words, and it does not mean that literally and simply fond of words of one language can be replaced by fond of words of other language. In words of one language is not only that what is outside, but also what is inside a man, gauzy nor meaning, their historic ethnologic portrait, etc.

Bosnian language today is a very important factor of Bosniak identity because, besides other, it remained in very turbulent and disinclined further and closer past regime. From such past it has preserved nearly four thousand words only in culinary, it has written monuments in more letters than anybody has (Glagolitic, Cyrilic, Bosančica, Matufica, Latin), for centuries it has been preserved in bilingualism (Arabic, Turkish, Persian, Latin, German) etc. Even today, many Turkish loanwords (Oriental loanwords) are used in it which do not feel like words from foreign languages (for example French, German, English), because original words have, in different ways of formational shaping, totally acclimated and within period of six centuries, accommodated into linguistic structure of Bosnian language. All that has today resulted in a kind of state in dictionary wealth of Bosnian language. An individual in his speech feeling owns two dictionaries: active (which consists of all words which one knows and which one uses daily) and passive (which consists of all words which one knows but many of which one rarely or no way uses, because one does not more or less consider it as its own identity). If an individual has managed to preserve and further develop its language in conditions of absolutely disinclined regimes, if language is active besides two vocabularies, it is evident that not only is it adequate to objective reality of its speakers, but it is also developing, because the people who speak it have subjected, perpetuated, expressed its emotion and thought, total ethnologic identity precisely by that language. That is why a reciprocal influence is preservation and development of: Bosnian language and Bosniak identity. 
Language is man's greatest freedom. Through language, individual and collective conscience is expressed. Problem of global language - local language is the best solution for bilingualism. Economic, military and political power represents also a linguistic power. One of the most important factors of Bosniak identity is Bosnian language. Customs, tradition, folklore, work, working means, working methods, culture and everything else that belongs to Bosniaks is preserved through it.

\section{REFERENCES}

Criystal, D. (2009). The Future of Language. London: Routledge. Kordić, S. (2010). Jezik $i$ nacionalizam [Language and Nationalism]. Zagreb, Croatia: Durieux.

Anić, V. (1998). Jezik i sloboda [Language and Freedom]. Zagreb, Croatia: Matica hrvatska. 